\title{
The influence of penicillin on Lactobacillus leichmannii serum $\mathrm{B}_{\mathrm{12}}$ assay
}

\author{
BORYS BOCZAROW \\ From the Department of Pathology, Stoke Mandeville Hospital, Aylesbury, Bucks.
}

SYNOPSIS The influence of penicillin on vitamin $\mathrm{B}_{12}$ assay using L. leichmannii as the test organism was investigated, and it was found that penicillin even in a low serum concentration invalidated the test.

The assay of vitamin $B_{12}$ in serum is now accepted as a routine laboratory test. In some laboratories the method using Lactobacillus leichmannii as the test organism is used in preference to the more time-consuming Euglena gracilis method. It gives satisfactory results and does not require special equipment but the fact that $L$. leichmannii used in the test is sensitive to antibiotics is sometimes ignored and specimens for the test are collected during antibiotic treatment. The purpose of this investigation is to draw attention to possible errors in $\mathrm{B}_{12}$ assay by using the L. leichmannii method on sera collected while patients were receiving penicillin.

\section{METHODS}

$B_{12}$ ASSAY IN SERUM A modification of methods described by Hawkins and Meynell (1958) and Cooper (1959) was used.

Medium Double strength Difco $\mathrm{B}_{12}$ assay broth was prepared according to the makers' instructions.

Preparation of serum extracts To 1 vol. of serum one fifth volume of $0.1 \%$ sodium cyanide and 1 vol. of acetate buffer, $p \mathrm{H} 4 \cdot 6$, were added. The mixture was left at room temperature for about $\mathbf{3 0}$ minutes and then distilled water was added to make a total of $10 \mathrm{vol}$. (If the water is added immediately after the buffer some extracts may be opalescent or milky; all extracts are water clear when the proper interval is observed.) The mixtures were placed in a boiling water bath for 30 minutes, cooled, and centrifuged. The clear supernatant extracts were used for the assay.

Preparation of inoculum A fresh, 24-36-hour-old culture of $L$. leichmannii in Difco inoculum broth was centrifuged and the deposit washed twice with sterile saline and then re-suspended in saline. The suspension was further diluted with saline till it was just slightly opalescent.

Procedure In the standard test two extract strengths are used, neat and diluted $1: 2 \cdot 5$. In this investigation

Received for publication 22 April 1960. extracts were used, neat and diluted $1: 2,1: 5,1: 10,1: 20$, 1:50. Sterile vitamin $B_{12}$ aqueous solutions containing 0 to $50 \mu \mu \mathrm{g}$. per ml. were prepared for the standard $B_{12}$ curve. To $5 \mathrm{ml}$. aliquots of neat and diluted extracts and of $B_{12}$ standard solutions in sterile tubes an equal amount of double-strength Difco $B_{12}$ assay broth and $0.1 \mathrm{ml}$. of $L$. leichmannii inoculum were added. The tubes were incubated anaerobically at $37^{\circ} \mathrm{C}$. for 36 hours. After incubation the cultures were diluted with an equal volume of $3 \% \mathrm{HCl}$ in saline and the opacity measured in a Unicam SP 500 spectrophotometer (wavelength 590 millimicrons, large tube with light path of $24 \mathrm{~mm}$.). Dilution with acid saline has two advantages: it confines all opacity readings in the test to the more sensitive part of the logarithmic scale and it produces a uniform yellow colour in all culture tubes, which, after incubation, are of different shades from reddish-brown to yellow.

DETERMINATION OF L. LEICHMANNII SENSITIVITY TO PENICILLIN A series of twofold dilutions of penicillin in sterile distilled water was prepared. The solutions contained between 0.0038 and 0.48 units of penicillin per $\mathrm{ml}$. To $5 \mathrm{ml}$. aliquots of each solution an equal amount of double-strength Difco $\mathrm{B}_{12}$ assay broth containing $50 \mu \mu \mathrm{g}$ of $\mathrm{B}_{12}$ per $\mathrm{ml}$. and $0.1 \mathrm{ml}$. of $L$. leichmannii inoculum were added. The tubes were incubated anaerobically at $37^{\circ} \mathrm{C}$. for 36 hours and the presence or absence of growth was read macroscopically.

PENICILLIN ASSAY IN SERUM AND SERUM EXTRACTS The method used was that described by Mackie and McCartney (1953). From both neat serum (or extract) and from its 1:100 dilution in sterile broth a series of twofold dilutions in sterile broth was prepared (from 1:1 to 1:64). At the same time a series of twofold penicillin dilutions in sterile broth containing between 0.0019 and 0.24 units per $\mathrm{ml}$. was also prepared. Then $0.3 \mathrm{ml}$. aliquots of all serum (or extract) and of penicillin dilutions were inoculated 
with a standard loopful of $1: 300$ dilution in broth of a 24-hour-old broth culture of the Oxford staphylococcus. The tubes were incubated overnight and the presence or absence of growth observed macroscopically.

The lowest penicillin concentration that inhibited growth of the Oxford staphylococcus was invariably 0.03 units per $\mathrm{ml}$. The same penicillin concentration was assumed to be present in the highest serum or extract dilution that inhibited growth of the Oxford staphylococcus.

\section{RESULTS}

The lowest level of penicillin in the serum to be assayed which might, by inhibiting the growth of the test organism, interfere with the assay depends on (1) the sensitivity of $L$. leichmannii to penicillin, (2) the dilution of the serum to be assayed, and (3) the loss of penicillin activity during preparation of extract.

L. LEICHMANNII SENSITIVITY TO PENICILLIN L. leichmannii was found to be resistant to 0.015 units per $\mathrm{ml}$. and sensitive to 0.03 units per ml. penicillin. These limits are the same as for the Oxford staphylococcus and this fact was found useful in this investigation.

LOSS OF PENICILLIN ACTIVITY IN SERUM EXTRACTS To evaluate the deterioration of penicillin activity during the preparation and storage of extracts penicillin levels in 12 sera and their extracts were determined and compared. The results are given in Table $I$.

TABLE I

PENICILLIN CONCENTRATIONS IN SERA AND THEIR EXTRACTS

\begin{tabular}{|c|c|c|c|c|}
\hline Sample & $\begin{array}{l}\text { Penicillin } \\
\text { Content } \\
\text { in } 1 \mathrm{ml} \text {. } \\
\text { Serum } \\
\text { (units) }\end{array}$ & $\begin{array}{l}\text { Penicillin } \\
\text { Content } \\
\text { in } 10 \mathrm{ml} . \\
\text { Extract } \\
\text { (units) }\end{array}$ & $\begin{array}{l}\text { Time between } \\
\text { Collection of Serum and } \\
\text { Preparation of Extract }\end{array}$ & $\begin{array}{l}\text { Residual } \\
\text { Penicillin } \\
\text { Activity in } \\
\text { Extract } \\
(\%)\end{array}$ \\
\hline 1 & $4 \cdot 8$ & $2 \cdot 4$ & Prepared from fresh serum & 50 \\
\hline 2 & $19 \cdot 2$ & $9 \cdot 6$ & Prepared from fresh serum & 50 \\
\hline 3 & 3.0 & $1 \cdot 2$ & Prepared from fresh serum & 40 \\
\hline 4 & $3 \cdot 0$ & $2 \cdot 4$ & Prepared from fresh serum & 80 \\
\hline 5 & $3 \cdot 0$ & $1 \cdot 2$ & 5 days & 40 \\
\hline 6 & $24 \cdot 0$ & $9 \cdot 6$ & 5 days & 40 \\
\hline 7 & $6 \cdot 0$ & $4 \cdot 8$ & 5 days & 80 \\
\hline 8 & $6 \cdot 0$ & $2 \cdot 4$ & 5 days & 40 \\
\hline 9 & $24 \cdot 0$ & $9 \cdot 6$ & 10 days & 40 \\
\hline 10 & 2.0 & $1 \cdot 2$ & 10 days & 60 \\
\hline 11 & $2 \cdot 0$ & 0.6 & 10 days & 30 \\
\hline 12 & 48.0 & $19 \cdot 2$ & 10 days & 40 \\
\hline
\end{tabular}

Serum penicillin concentrations were estimated on fresh sera and again after they had been stored frozen at $-40^{\circ} \mathrm{C}$. for 10 days. There was no deterioration in penicillin activity after storage. On the other hand, some penicillin activity was lost during preparation of extracts. The residual activity was $\frac{\mathrm{O}}{\mathrm{O}}$ between $30 \%$ and $80 \%$ of that originally present in the serum. The double dilution method used for $\stackrel{\sim}{\rightarrow}$ penicillin assay is not very accurate and, therefore, the figures in Table I give only approximate values.

L. LEICHMANNII ASSAYS ON SERA FROM PATIENTS $\stackrel{\mathbb{\complement}}{\varrho}$ RECEIVING PENICILLIN The inhibitory action of $\%$ penicillin on $L$. leichmannii explains findings in $\vec{\circ}$ routine $B_{12}$ assay work when on some occasions the presence of penicillin in tested sera invalidated the $\vec{\omega}$ test. The results obtained in five sera submitted for $?$ routine $B_{12}$ assay from patients who were being? treated with penicillin are shown in Fig. 1. $A \vec{A}$ striking finding in these five tests was the complete i inhibition of growth of L. leichmannii in tubes con- $\vec{\infty}$ taining large concentrations of serum extracts. These are the concentrations used in routine $B_{12}$ assay
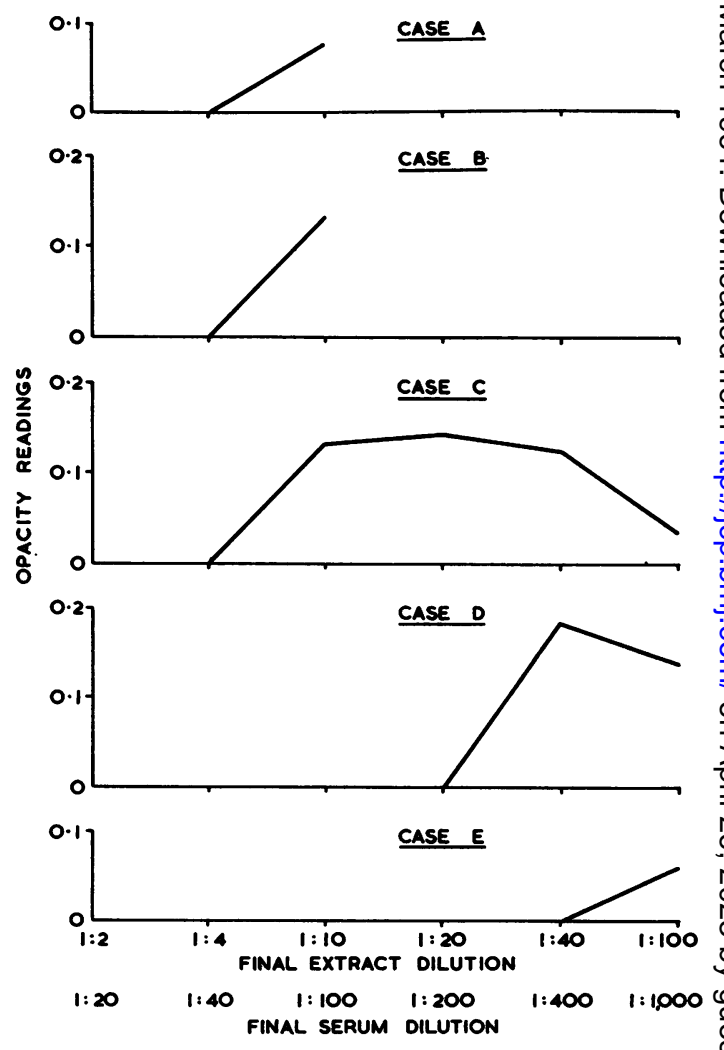

FIG. 1. Opacity readings in $B_{12}$ assay on five sera collected during penicillin treatment. Penicillin content in extracts: Case $A, 0.06$ units $/ \mathrm{ml}$.; Case $B, 0.12$ units $/ \mathrm{ml}$.; Case $C, \stackrel{\mathbb{D}}{\stackrel{D}{ }}$ 0.24 units $/ \mathrm{ml}$.; Case D, 1.0 unit $/ \mathrm{ml}$.; Case E, 1.9 unit $/ \mathrm{ml} . \stackrel{\mathrm{D}}{\mathrm{D}}$ Penicillin levels in sera: Case A, 2.0 unit/ml.; Case $E$, 48.0 unit/ml.; there was insufficient serum in the remaining three cases. 
(extracts diluted $1: 2$ and $1: 5$ corresponding to serum dilutions of $1: 20$ and $1: 50$ ). The inhibition corresponded roughly to the pencillin level in the extract. In Cases $\mathrm{A}, \mathrm{B}$, and $\mathrm{C}$, in which extract penicillin levels were less than 0.25 units per ml., the growth of L. leichmannii was completely inhibited in the first two tubes only. In Case $D$, in which extract penicillin level was 1 unit per ml., there was no growth in the first four tubes, and in Case $\mathrm{E}$ with an extract penicillin level of 1.9 units per ml. in the first five tubes. Such complete lack of growth in culture tubes inoculated with $L$. leichmannii is never found when sera are free from penicillin. Even with sera from patients with pernicious anaemia in those tubes containing the least amount of extract there is always a slight turbidity visible to the naked eye.

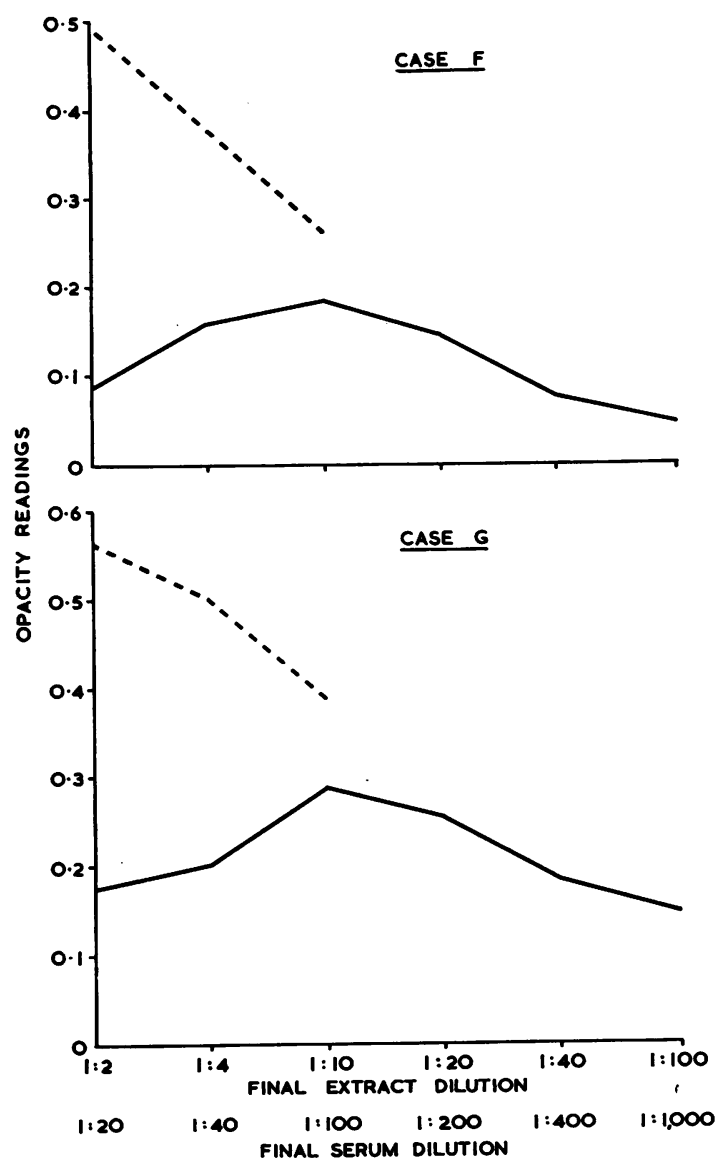

FIG. 2. Opacity readings in serum $B_{12}$ assays before and during penicillin treatment (interrupted line - - before, continuous line_during penicillin treatment). Penicillin doses, serum penicillin levels, and calculated serum $B_{12}$ values are given in Table II.
While penicillin interference should not be missed in cases where growth of $L$. leichmannii is completely inhibited, it is less easily recognized in tests where extract penicillin levels are so low that growth of $L$. leichmannii is only partly inhibited. Two such cases are shown in Fig. 2. These two patients were treated with fairly low doses of penicillin (Case F, Broxil tablets, $500 \mathrm{mg}$. daily, and Case G, penicillin injections, 500,000 units daily). Two blood specimens for $B_{12}$ assay were collected from each patient, one before and another on the second day of penicillin treatment. It was assumed that there would be no significant difference in $B_{12}$ levels between two specimens collected at such short intervals. There was a marked difference in the appearance of opacity curves between the first and the second specimens. The specimens collected before penicillin treatment showed a more or less regular slope, while the specimens collected during treatment produced a curve of unusual shape. The growth of $L$. leichmannii was scanty in the first tubes containing undiluted extract. It increased with each dilution till the peak was reached and then diminished with further dilutions. The first, rising part of the curve was obviously related to penicillin and not to $\mathbf{B}_{12}$ concentration. The peak values in both cases were less than in corresponding dilutions of penicillinfree extracts and could not be accepted as representing true $B_{12}$ concentrations. The serum $B_{12}$ levels calculated from each dilution are shown in Table II.

TABLE II SERUM $B_{12}$ VALUES CALCULATED FROM OPACITY
READINGS SHOWN IN FIG. 2

\begin{tabular}{|c|c|c|c|c|c|c|}
\hline \multirow[t]{2}{*}{ Case } & \multirow[t]{2}{*}{ Sample } & \multirow{2}{*}{$\begin{array}{l}\text { Penicillin } \\
\text { Dose }\end{array}$} & \multirow{2}{*}{$\begin{array}{l}\text { Serum } \\
\text { Penicillin } \\
\text { Level } \\
\text { (units/ml.) }\end{array}$} & \multicolumn{3}{|c|}{ Extract Dilutions ${ }^{1}$} \\
\hline & & & & $\frac{1}{2}(1 / 20)$ & $\frac{1}{2}(1 / 40)$ & 18 $(1 / 100)$ \\
\hline \multirow[b]{2}{*}{$\mathbf{F}$} & 1 & - & - & 510 & 480 & 500 \\
\hline & 2 & $\begin{array}{l}\text { Oral Broxil, } \\
500 \text { mg. daily }\end{array}$ & 0.06 & 10 & 80 & 250 \\
\hline \multirow[b]{2}{*}{$\mathbf{G}$} & 1 & - & - & 2 & 1000 & 1100 \\
\hline & 2 & $\begin{array}{l}\text { Penicillin, } 500 \\
\text { u. i.m. daily }\end{array}$ & 0.12 & 32 & 700 & 550 \\
\hline
\end{tabular}

${ }^{1}$ Corresponding serum dilutions are shown in brackets. ${ }^{2}$ Opacity too high, outside standard curve range.

Dilutions in the descending part of the curve were outside the useful range. It was also possible that the growth of $L$. leichmannii in these tubes was still influenced by traces of penicillin.

\section{DISCUSSION}

The examples described above show that the low concentrations of penicillin in serum, which can be 
expected in practically every case treated with penicillin, will invalidate $B_{12}$ assay by the L. leichmannii method. When the penicillin level is high enough to cause complete inhibition of growth the fact is easily noticed. A partial inhibition of growth by smaller concentrations of penicillin in serum may not attract attention and consequently false low values may be erroneously reported.

When the serum $B_{12}$ level has to be estimated during penicillin treatment it should be done by the Euglena gracilis method. Ross (1952) found that 'sulphathiazole, penicillin, streptomycin, aureomycin, chloramphenicol, and para-aminosalicylic acid when added in concentration likely to be found in human serum during treatment with these drugs were without significant effect on growth of Euglena gracilis'. Lear, Harris, Castle, and Fleming (1954), on the other hand, reported that 'sulphonamide derivatives may be present in serum in concentrations which can inhibit Euglena growth'. Hutner, Bach, 을 and Ross (1956) showed that the addition of paraaminobenzoic acid to the basal medium abolished $\stackrel{\vec{F}}{\stackrel{9}{9}}$ the inhibitory effect of sulphonamides but did not? interfere with the growth of Euglena gracilis in serum $B_{12}$ assay.

I wish to thank Dr. C. L. Greenbury for his encouragement and advice in the preparation of this paper.

\section{REFERENCES}

Cooper, B. A. (1959). J. clin. Path., 12, 153. Cooper, B. A. (1959). J. clin. Path., 12, 153.
Hawkins, C. F., and Meynell, M. J. (1958). Quart. J. Med., n.s. 27,
61 .

Hutner, S. H., Bach, M. K., and Ross, G. I. M. (1956). J. Protozool., 3, 101.

Lear, A. A., Harris, J. W., Castle, W. B., and Fleming, E. M. (1954). $\vec{\varnothing}$ J. Lab. clin. Med., 44, 715.

Mackie, T. J., and McCartney, J. E. (1953). Handbook of Practical을 Bacteriology, 9th ed., p. 311.

Ross, G. I. M. (1952). J. clin. Path., 5, 250. 